J Electrocardiol. 2011 November ; 44(6): 656-661. doi:10.1016/j.jelectrocard.2011.07.026.

\title{
J Wave Syndromes. From Cell to Bedside
}

\author{
Charles Antzelevitch, $\mathrm{PhD}^{1}$ and Gan-Xin Yan, MD, $\mathrm{PhD}^{2,3}$ \\ ${ }^{1}$ Masonic Medical Research Laboratory, Utica, NY, USA \\ ${ }^{2}$ Main Line Health Heart Center and Lankenau Institute for Medical Research, Wynnewood, PA, \\ USA \\ 3Jefferson Medical College, Philadelphia, PA, USA
}

\begin{abstract}
The $\mathbf{J}$ wave, a deflection that follows the QRS complex of the surface ECG, is usually partially buried in the $\mathrm{R}$ wave in humans, appearing as a $\mathrm{J}$ point elevation. An early repolarization (ER) pattern characterized by J point elevation, slurring of the terminal part of the QRS and ST segment elevation has long been recognized and considered to be totally benign. Recent studies have presented evidence demonstrating that an ER pattern in inferior leads or infero-lateral leads is associated with increased risk for life-threatening arrhythmias, named early repolarization syndrome (ERS). ERS and Brugada syndrome (BrS) share similar ECG characteristics, clinical outcomes, risk factors as well as a common arrhythmic platform related to amplification of $\mathrm{I}_{\mathrm{to}^{-}}$ mediated $\mathrm{J}$ waves. Although $\mathrm{BrS}$ and early repolarization syndrome (ERS) differ with respect to the magnitude and lead location of abnormal $\mathbf{J}$ wave manifestation, they can be considered to represent a continuous spectrum of phenotypic expression, termed $\mathbf{J}$ wave syndromes. ERS has been proposed to be divided into three subtypes: Type 1, displaying an ER pattern predominantly in the lateral precordial leads, is prevalent among healthy male athletes and rarely seen in VF survivors; Type 2, displaying an ER pattern predominantly in the inferior or infero-lateral leads, is associated with a higher level of risk; whereas Type 3, displaying an ER pattern globally in the inferior, lateral and right precordial leads, is associated with the highest level of risk for development of malignant arrhythmias and is often associated with VF storms.
\end{abstract}

\section{Keywords}

Cardiac arrhythmias; Sudden cardiac death; Sudden cardiac arrest; Transient outward current; J point elevation; Early repolarization syndrome; Brugada syndrome; Idiopathic Ventricular fibrillation; Hypothermia; STEMI

The $\mathrm{J}$ wave is a deflection that follows the QRS complex on the surface electrocardiogram (ECG). When partially buried in the $\mathrm{R}$ wave, the $\mathrm{J}$ wave appears as a $\mathrm{J}$ point elevation and may be accompanied by an ST segment elevation, an ECG feature referred to as an early repolarization (ER) pattern. Recent studies have provided evidence in support of an

() 2011 Elsevier Inc. All rights reserved.

Address for correspondence: Charles Antzelevitch, PhD, FHRS, FACC, FAHA, Executive Director and Director of Research, Gordon K. Moe Scholar, Masonic Medical Research Laboratory, 2150 Bleecker Street, Utica, NY 13501, Phone: (315)735-2217, FAX: (315)735-5648, ca@mmrl.edu.

Publisher's Disclaimer: This is a PDF file of an unedited manuscript that has been accepted for publication. As a service to our customers we are providing this early version of the manuscript. The manuscript will undergo copyediting, typesetting, and review of the resulting proof before it is published in its final citable form. Please note that during the production process errors may be discovered which could affect the content, and all legal disclaimers that apply to the journal pertain.

Conflicts of Interest: There are no conflicts of interest to disclose. 
association of ER pattern with life-threatening arrhythmias, designated as early repolarization syndrome (ERS) or Brugada syndrome $(\mathrm{BrS})$ based on the region of the heart responsible for the arrhythmogenic substrate. Although BrS and ERS differ with respect to the magnitude and lead location of abnormal $\mathrm{J}$ wave manifestation, they are thought to represent a continuous spectrum of phenotypic expression termed $\mathbf{J}$ wave syndromes ${ }^{1}$.

The early repolarization pattern, consisting of a distinct $\mathrm{J}$ wave or $\mathrm{J}$ point elevation, a notch or slur of the terminal part of the QRS and an ST segment elevation, is predominantly found in healthy young males and has traditionally been viewed as benign 2,3 . Our observation in 2000 that an ER pattern in the canine coronary-perfused wedge preparation can easily convert to one in which phase 2 reentry gives rise to polymorphic ventricular tachycardia/ ventricular fibrillation (VT/VF), prompted the suggestion that ER may in some cases predispose to malignant arrhythmias in the clinic $^{1,4,5}$. A number of case reports and experimental studies have suggested a critical role for the $\mathrm{J}$ wave in the pathogenesis of idiopathic ventricular fibrillation (IVF) ${ }^{6-14}$. A definitive association between ER and IVF was presented in the form of two studies published in the New England Journal of Medicine in $2008{ }^{15,16}$ These were followed by another study from Viskin and co-workers ${ }^{17}$ that same year and two large population association studies in 2009 and 2010. ${ }^{18,19}$.

Based on the available clinical data, we recently suggested a classification scheme that attempts to risk stratify patients with ER. ${ }^{1}$. An ER pattern manifest exclusively in the lateral precordial leads was designated as Type 1 ; this form is prevalent among healthy male athletes and is thought to be associated with a relatively low level of risk for arrhythmic events. ER pattern in the inferior or infero-lateral leads was designated as Type 2; this form is thought to be associated with a moderate level of risk. Finally, an ER pattern appearing globally in the inferior, lateral and right precordial leads was labeled Type 3; this form is associated with the highest level of risk and in some cases has been associated with electrical storms ${ }^{1}$. BrS represents a fourth variant in which ER is limited to the right precordial leads.

\section{Ionic and Cellular Basis for the $\mathrm{J}$ wave and Associated Arrhythmogenesis}

Transmural differences in the early phases of the action potential have long been recognized as the basis for inscription of the electrocardiographic $\mathrm{J}$ wave. ${ }^{20,21}$ The ventricular epicardial action potential, particularly in the right ventricle, displays a prominent transient outward current $\left(\mathrm{I}_{\mathrm{to}}\right)$-mediated notch or spike and dome morphology. The presence of a prominent $\mathrm{I}_{\mathrm{to}}$-mediated action potential notch in ventricular epicardium but not endocardium produces a transmural voltage gradient that registers as a $\mathbf{J}$ wave or $\mathbf{J}$ point elevation on the ECG. Direct evidence in support of this hypothesis was first obtained in arterially-perfused canine ventricular wedge preparations ${ }^{7}$ as illustrated in Figure 1. Factors that influence $I_{\text {to }}$ kinetics or ventricular activation sequence can modify the manifestation of the $\mathbf{J}$ wave on the ECG. Whether reduced by $\mathrm{I}_{\mathrm{to}}$ blockers such as 4-aminopyridine or premature activation or augmented by exposure to hypothermia, changes in the magnitude of the epicardial action potential notch parallel those of the $\mathrm{J}$ wave. ${ }^{22,23}$

Augmentation of net repolarizing current, secondary to a decrease of inward currents or an increase of outward current, accentuates the notch leading to augmentation of the $\mathrm{J}$ wave or appearance of ST segment elevation. A further increase in net repolarizing current can result in partial or complete loss of the action potential dome, leading to a transmural voltage gradient that manifests as accentuation of the $\mathrm{J}$ wave or an ST segment elevation. ${ }^{5,22,23}$ In regions of the myocardium exhibiting a prominent $\mathrm{I}_{\mathrm{to}}$, such as the right ventricular epicardium, marked accentuation of the action potential notch and a coved-type ST segment elevation diagnostic of BrS (Fig. 2B). A further outward shift of the currents active during 
the early phase of the action potential can lead to loss of the action potential dome, thus creating a dispersion of repolarization between epicardium and endocardium as well as within epicardium, between the region where the dome is lost and regions at which it is maintained (Fig. 2C). Sodium channel blockers like procainamide, pilsicainide, propafenone, flecainide and disopyramide cause a further outward shift of current flowing during the early phases of the action potential and therefore effective in inducing or unmasking ST segment elevation in patients with concealed J-wave syndromes. ${ }^{24-26}$ Sodium channel blockers like quinidine, which also inhibits $\mathrm{I}_{\mathrm{to}}$, reduce the magnitude of the $\mathrm{J}$ wave and normalize ST segment elevation. ${ }^{5,27}$ Loss of the action potential dome is usually heterogeneous, resulting in marked abbreviation of action potential at some sites but not others. The dome can then propagates from regions where it is maintained to regions where it is lost, giving rise to a very closely coupled extrasystole via phase 2 reentry (Fig. 2D). ${ }^{28}$ The phase 2 reentrant beat can then initiate a polymorphic ventricular tachycardia (VT) or ventricular fibrillation (Figs. 2E and F).

The outward shift of current may extend beyond the action potential notch and thus lead to depression of the dome in addition to accentuating the $\mathrm{J}$ wave. Activation of the ATPsensitive potassium current ( $\left.\mathrm{I}_{\mathrm{K}-\mathrm{ATP}}\right)$ or depression of inward calcium channel current $\left(\mathrm{I}_{\mathrm{Ca}}\right)$ can effect such a change (Figs. 3A and B). This is more likely to manifest in the ECG as an ER pattern consisting of a J point elevation, slurring of the terminal part of the QRS and mild ST segment elevation. The ER pattern can facilitate loss of the dome due to other factors and thus lead to the development of ST segment elevation, phase 2 reentry and VT/ VF. (Fig. 3C and D).

\section{Clinical manifestations of $\mathbf{J}$ wave syndromes}

In both ERS and BrS, the manifestation of the J wave or ER is dynamic ${ }^{14,29,30}$, with the most prominent ECG changes appearing just before the onset of VT/VF $7-14,29-31$. Other ECG characteristics of ERS also closely match those of BrS, including the presence of accentuated J waves, pause and bradycardia-dependence, short coupled extrasystole-induced polymorphic VT/VF. Suppression of the ECG features by isoproterenol or pacing in ER patients further supports the notion that they share common underlying electrophysiologic abnormalities with BrS patients. ${ }^{31}$ However, salient diagnostic features of $\mathrm{BrS}$ such as provocation by sodium channel blockers or positive signal averaged ECG are rarely observed in these IVF patients. ${ }^{16,31}$

$\mathrm{BrS}$ has been associated with mutations in ten different genes. Over 300 mutations in $S C N 5 A\left(\mathrm{Na}_{\mathrm{v}} 1.5, \mathrm{BrS} 1\right)$ have been reported in $11-28 \%$ of BrS probands. ${ }^{32-34}$ Mutations in CACNAIC $\left(\mathrm{Ca}_{\mathrm{v}} 1.2, \mathrm{BrS} 3\right), C A C N B 2 b\left(\mathrm{Ca}_{\mathrm{v}} \beta 2 \mathrm{~b}, \mathrm{BrS} 4\right)$ and $C A C N A 2 D 1\left(\mathrm{Ca}_{\mathrm{v}} \alpha 2 \delta, \mathrm{BrS} 9\right)$ are found in approximately $13 \%$ of probands. ${ }^{35,36}$ Mutations in glycerol-3-phophate dehydrogenase 1-like enzyme gene (GPDIL, BrS2), SCN1B ( $\beta_{1}$-subunit of Na channel, BrS5), KCNE3 (MiRP2; BrS6), SCN3B ( 33 -subunit of Na channel, BrS7), KCNJ8 (BrS8) and $K C N D 3$ (BrS10) are more rare. ${ }^{37-42}$ Mutations in these genes lead to loss of function in $\mathrm{I}_{\mathrm{Na}}$ and $\mathrm{I}_{\mathrm{Ca}}$, as well as to a gain of function in $\mathrm{I}_{\mathrm{to}}$ or $\mathrm{I}_{\mathrm{K}-\mathrm{ATP}}$.

The genetic basis for ER is slowly coming into better focus. Consistent with the findings that $\mathrm{I}_{\mathrm{K}-\mathrm{ATP}}$ activation can generate an ER pattern in canine ventricular wedge preparations, a rare variant in $K C N J 8$, responsible for the pore forming subunit of the $\mathrm{I}_{\mathrm{K}-\mathrm{ATP}}$ channel, has recently been reported in a patient with ERS; expression studies are not available as yet. ${ }^{43}$ Recent studies from our group have recently identified loss of function mutations in the $\alpha 1$ and $\beta 2$ and $\alpha 2 \delta$ subunits of the cardiac L-type calcium channel (CACNAIC, CACNB2, and CACNA2D1) in patients with ERS. ${ }^{36}$ 
As in most cases of BrS, bradycardia accentuates ST segment elevation, and tachycardia tends to normalize the ST segment in ERS. VF often occurs near midnight or in the early morning hours when heart rate is slower and parasympathetic tone is augmented. ${ }^{10,44}$

In $\mathrm{BrS}$, the manifestation of spontaneous ST segment elevation has been associated with a higher risk for development of arrhythmic events. Risk stratification of asymptomatic patients remains a challenge. In the case of ERS, it is clear that the vast majority of individuals with ER are at no or minimal risk for arrhythmic events and sudden cardiac arrest. Our challenge moving forward is to develop better risk stratification strategies and effective treatments for the $\mathrm{J}$ wave syndromes.

Our working hypothesis is that an outward shift in repolarizing current due to a decrease in sodium or calcium channel currents or an increase in $\mathrm{I}_{\text {to }}, \mathrm{I}_{\mathrm{K}-\mathrm{ATP}}, \mathrm{I}_{\mathrm{K}-\mathrm{ACh}}$, or other outward currents gives rise to the $\mathrm{J}$ wave syndromes (Fig. 4). The particular phenotype depends on what part of the heart is principally affected and which ion channels are involved. We view the $\mathrm{J}$ wave syndromes as a spectrum of disorders that involve accentuation of the epicardial action potential notch in different regions of heart, leading to the development of prominent $\mathrm{J}$ waves that predispose to the development of VT/VF.

In the case of $\mathrm{BrS}$, the appearance of prominent $\mathrm{J}$ waves is limited to the leads facing the right ventricular outflow tract where $\mathrm{I}_{\text {to }}$ is most prominent. The more prominent $\mathrm{I}_{\text {to }}$ in right ventricular epicardium provides for an outward shift in the balance of current which promotes the appearance of the $\mathrm{J}$ wave in this region of the ventricular myocardium. In the case of ERS, the appearance of prominent $J$ waves may be limited to other regions of the ventricular myocardium because of the presence of heterogeneities in the distribution of other currents such as $\mathrm{I}_{\mathrm{K}-\mathrm{ATP}}$.

\section{Risk stratification}

While it is clear that the vast majority of individuals presenting with an ER pattern in the ECG are at no or minimal risk, the challenge currently facing the cardiology community is how to distinguish ER patterns in healthy individuals from those who carry significant arrhythmic risk. In addition to the classification scheme proposed ${ }^{1}$, available data suggest that a $\mathrm{J}$ point elevation of $>0.2 \mathrm{mV}^{18}$, accompanying short QTc intervals ${ }^{45}$ or distinct $\mathrm{J}$ waves ${ }^{46}$ should raise a red flag. A recent study by Tikkanen and coworkers reports that a rapidly ascending ST segment after the J-point, the dominant ST pattern found in healthy athletes, seems to be a benign variant of ER, whereas a horizontal or descending ST segment elevation is associated with an increased risk for arrhythmic death. ${ }^{47}$

\section{Acknowledgments}

Supported by HL47678 from NHLBI (CA), Masons of New York State and Florida (CA)

\section{Reference List}

1. Antzelevitch C, Yan GX. J wave syndromes. Heart Rhythm. 2010; 7:549-558. [PubMed: 20153265]

2. Wasserburger RH, Alt WJ. The normal RS-T segment elevation variant. Am J Cardiol. 1961; 8:184192. [PubMed: 13783301]

3. Mehta MC, Jain AC. Early repolarization on scalar electrocardiogram. Am J Med Sci. 1995; 309:305-311. [PubMed: 7771499]

4. Gussak I, Antzelevitch C. Early repolarization syndrome: clinical characteristics and possible cellular and ionic mechanisms. J Electrocardiol. 2000; 33:299-309. [PubMed: 11099355] 
5. Yan GX, Antzelevitch C. Cellular basis for the Brugada syndrome and other mechanisms of arrhythmogenesis associated with ST segment elevation. Circulation. 1999; 100:1660-1666. [PubMed: 10517739]

6. Bjerregaard P, Gussak I, Kotar Sl, Gessler JE. Recurrent synocope in a patient with prominent Jwave. Am Heart J. 1994; 127:1426-1430. [PubMed: 8172079]

7. Yan GX, Antzelevitch C. Cellular basis for the electrocardiographic J wave. Circulation. 1996; 93:372-379. [PubMed: 8548912]

8. Geller JC, Reek S, Goette A, Klein HU. Spontaneous episode of polymorphic ventricular tachycardia in a patient with intermittent Brugada syndrome. J Cardiovasc Electrophysiol. 2001; 12:1094. [PubMed: 11573705]

9. Daimon M, Inagaki M, Morooka S, Fukuzawa S, Sugioka J, Kushida S, Tateno K, Ozawa S. Brugada syndrome characterized by the appearance of J waves. PACE. 2000; 23:405-406. [PubMed: 10750145]

10. Kalla H, Yan GX, Marinchak R. Ventricular fibrillation in a patient with prominent J (Osborn) waves and ST segment elevation in the inferior electrocardiographic leads: a Brugada syndrome variant? J Cardiovasc Electrophysiol. 2000; 11:95-98. [PubMed: 10695469]

11. Komiya N, Imanishi R, Kawano H, Shibata R, Moriya M, Fukae S, Doi Y, Nakao K, Seto S, Yano $\mathrm{K}$. Ventricular fibrillation in a patient with prominent $\mathrm{J}$ wave in the inferior and lateral electrocardiographic leads after gastrostomy. PACE. 2006; 29:1022-1024. [PubMed: 16981930]

12. Shinohara T, Takahashi N, Saikawa T, Yoshimatsu H. Characterization of J wave in a patient with idiopathic ventricular fibrillation. Heart Rhythm. 2006; 3:1082-1084. [PubMed: 16945806]

13. Riera AR, Ferreira C, Schapachnik E, Sanches PC, Moffa PJ. Brugada syndrome with atypical ECG: downsloping ST-segment elevation in inferior leads. J Electrocardiol. 2004; 37:101-104. [PubMed: 15127375]

14. Shu J, Zhu T, Yang L, Cui C, Yan GX. ST-segment elevation in the early repolarization syndrome, idiopathic ventricular fibrillation, and the Brugada syndrome: cellular and clinical linkage. J Electrocardiol. 2005; 38:26-32. [PubMed: 16226071]

15. Haissaguerre M, Derval N, Sacher F, Jesel L, Deisenhofer I, De Roy L, Pasquie JL, Nogami A, Babuty D, Yli-Mayry S, De Chillou C, Scanu P, Mabo P, Matsuo S, Probst V, Le Scouarnec S, Defaye P, Schlaepfer J, Rostock T, Lacroix D, Lamaison D, Lavergne T, Aizawa Y, Englund A, Anselme F, O'Neill M, Hocini M, Lim KT, Knecht S, Veenhuyzen GD, Bordachar P, Chauvin M, Jais P, Coureau G, Chene G, Klein GJ, Clementy J. Sudden cardiac arrest associated with early repolarization. N Engl J Med. 2008; 358:2016-2023. [PubMed: 18463377]

16. Nam GB, Kim YH, Antzelevitch C. Augmentation of J waves and electrical storms in patients with early repolarization. N Engl J Med. 2008; 358:2078-2079. [PubMed: 18463391]

17. Rosso R, Kogan E, Belhassen B, Rozovski U, Scheinman MM, Zeltser D, Halkin A, Steinvil A, Heller K, Glikson M, Katz A, Viskin S. J-point elevation in survivors of primary ventricular fibrillation and matched control subjects: incidence and clinical significance. J Am Coll Cardiol. 2008; 52:1231-1238. [PubMed: 18926326]

18. Tikkanen JT, Anttonen O, Junttila MJ, Aro AL, Kerola T, Rissanen HA, Reunanen A, Huikuri HV. Long-term outcome associated with early repolarization on electrocardiography. N Engl J Med. 2009; 361:2529-2537. [PubMed: 19917913]

19. Sinner MF, Reinhard W, Muller M, Beckmann BM, Martens E, Perz S, Pfeufer A, Winogradow J, Stark K, Meisinger C, Wichmann HE, Peters A, Riegger GA, Steinbeck G, Hengstenberg C, Kaab S. Association of early repolarization pattern on ecg with risk of cardiac and all-cause mortality: a population-based prospective cohort study (MONICA/KORA). PLoS Med. 2010; 7:e1000314. [PubMed: 20668657]

20. Litovsky SH, Antzelevitch C. Transient outward current prominent in canine ventricular epicardium but not endocardium. Circ Res. 1988; 62:116-126. [PubMed: 2826039]

21. Antzelevitch C, Sicouri S, Litovsky SH, Lukas A, Krishnan SC, Di Diego JM, Gintant GA, Liu DW. Heterogeneity within the ventricular wall. Electrophysiology and pharmacology of epicardial, endocardial, and M cells. Circ Res. 1991; 69:1427-1449. [PubMed: 1659499]

22. Antzelevitch C, Yan GX. Cellular and ionic mechanisms responsible for the Brugada syndrome. J Electrocardiol. 2000; 33 Suppl:33-39. [PubMed: 11265734] 
23. Yan GX, Lankipalli RS, Burke JF, Musco S, Kowey PR. Ventricular repolarization components on the electrocardiogram: cellular basis and clinical significance. J Am Coll Cardiol. 2003; 42:401409. [PubMed: 12906963]

24. Shimizu W, Antzelevitch C, Suyama K, Kurita T, Taguchi A, Aihara N, Takaki H, Sunagawa K, Kamakura S. Effect of sodium channel blockers on ST segment, QRS duration, and corrected QT interval in patients with Brugada syndrome. J Cardiovasc Electrophysiol. 2000; 11:1320-1329. [PubMed: 11196553]

25. Brugada R, Brugada J, Antzelevitch C, Kirsch GE, Potenza D, Towbin JA, Brugada P. Sodium channel blockers identify risk for sudden death in patients with ST-segment elevation and right bundle branch block but structurally normal hearts. Circulation. 2000; 101:510-515. [PubMed: 10662748]

26. Morita H, Morita ST, Nagase S, Banba K, Nishii N, Tani Y, Watanabe A, Nakamura K, Kusano KF, Emori T, Matsubara H, Hina K, Kita T, Ohe T. Ventricular arrhythmia induced by sodium channel blocker in patients with Brugada syndrome. J Am Coll Cardiol. 2003; 42:1624-1631. [PubMed: 14607450]

27. Gussak I, Antzelevitch C, Bjerregaard P, Towbin JA, Chaitman BR. The Brugada syndrome: clinical, electrophysiologic and genetic aspects. J Am Coll Cardiol. 1999; 33:5-15. [PubMed: 9935001]

28. Krishnan SC, Antzelevitch C. Flecainide-induced arrhythmia in canine ventricular epicardium. Phase 2 reentry? Circulation. 1993; 87:562-572. [PubMed: 8425300]

29. Kasanuki H, Ohnishi S, Ohtuka M, Matsuda N, Nirei T, Isogai R, Shoda M, Toyoshima Y, Hosoda $\mathrm{S}$. Idiopathic ventricular fibrillation induced with vagal activity in patients without obvious heart disease. Circulation. 1997; 95:2277-2285. [PubMed: 9142005]

30. Matsuo K, Shimizu W, Kurita T, Inagaki M, Aihara N, Kamakura S. Dynamic changes of 12-lead electrocardiograms in a patient with Brugada syndrome. J Cardiovasc Electrophysiol. 1998; 9:508-512. [PubMed: 9607459]

31. Nam GB, Ko KH, Kim J, Park KM, Rhee KS, Choi KJ, Kim YH, Antzelevitch C. Mode of onset of ventricular fibrillation in patients with early repolarization pattern vs. Brugada syndrome. Eur Heart J. 2010; 31:330-339. [PubMed: 19880418]

32. Chen Q, Kirsch GE, Zhang D, Brugada R, Brugada J, Brugada P, Potenza D, Moya A, Borggrefe M, Breithardt G, Ortiz-Lopez R, Wang Z, Antzelevitch C, O'Brien RE, Schultze-Bahr E, Keating MT, Towbin JA, Wang Q. Genetic basis and molecular mechanisms for idiopathic ventricular fibrillation. Nature. 1998; 392:293-296. [PubMed: 9521325]

33. Schulze-Bahr E, Eckardt L, Breithardt G, Seidl K, Wichter T, Wolpert C, Borggrefe M, Haverkamp W. Sodium channel gene (SCN5A) mutations in 44 index patients with Brugada syndrome: different incidences in familial and sporadic disease. Hum Mutat. 2003; 21:651-652. [PubMed: 14961552]

34. Kapplinger JD, Wilde AAM, Antzelevitch C, Benito B, Berthet M, Brugada J, Brugada P, Fressart V, Guerchicoff A, Guicheney P, Kamakura S, Koopmann TT, Miyamoto M, Pollevick GD, Pfeiffer R, Probst V, Salisbury BA, Schulze-Bahr E, Shimizu W, Towbin JA, Vatta M, Zumhagen S, Schott J, Brugada R, Ackerman MJ. A worldwide compendium of putative Brugada syndrome associated mutations in the SCN5A encoded cardiac sodium channel. Heart Rhythm. 2009; 6:S392. Abstract.

35. Antzelevitch C, Pollevick GD, Cordeiro JM, Casis O, Sanguinetti MC, Aizawa Y, Guerchicoff A, Pfeiffer R, Oliva A, Wollnik B, Gelber P, Bonaros EP Jr, Burashnikov E, Wu Y, Sargent JD, Schickel S, Oberheiden R, Bhatia A, Hsu LF, Haissaguerre M, Schimpf R, Borggrefe M, Wolpert C. Loss-of-function mutations in the cardiac calcium channel underlie a new clinical entity characterized by ST-segment elevation, short QT intervals, and sudden cardiac death. Circulation. 2007; 115:442-449. [PubMed: 17224476]

36. Burashnikov E, Pfeiffer R, Barajas-Martinez H, Delpon E, Hu D, Desai M, Borggrefe M, Haissaguerre M, Kanter R, Pollevick GD, Guerchicoff A, Laino R, Marieb M, Nademanee K, Nam GB, Robles R, Schimpf R, Stapleton DH, Viskin S, Winters S, Wolpert C, Zimmern S, Veltmann C, Antzelevitch C. Mutations in the cardiac L-type calcium channel associated J wave sydnrome and sudden cardiac death. Heart Rhythm. 2010; 7:1872-1882. [PubMed: 20817017] 
37. London B, Michalec M, Mehdi H, Zhu X, Kerchner L, Sanyal S, Viswanathan PC, Pfahnl AE, Shang LL, Madhusudanan M, Baty CJ, Lagana S, Aleong R, Gutmann R, Ackerman MJ, McNamara DM, Weiss R, Dudley SC Jr. Mutation in glycerol-3-phosphate dehydrogenase 1 like gene (GPD1-L) decreases cardiac $\mathrm{Na}^{+}$current and causes inherited arrhythmias. Circulation. 2007; 116:2260-2268. [PubMed: 17967977]

38. Watanabe H, Koopmann TT, Le Scouarnec S, Yang T, Ingram CR, Schott JJ, Demolombe S, Probst V, Anselme F, Escande D, Wiesfeld AC, Pfeufer A, Kaab S, Wichmann HE, Hasdemir C, Aizawa Y, Wilde AA, Roden DM, Bezzina CR. Sodium channel b1 subunit mutations associated with Brugada syndrome and cardiac conduction disease in humans. J Clin Invest. 2008; 118:22602268. [PubMed: 18464934]

39. Delpón E, Cordeiro JM, Núñez L, Thomsen PEB, Guerchicoff A, Pollevick GD, Wu Y, Kanters JK, Larsen CT, Burashnikov A, Christiansen M, Antzelevitch C. Functional effects of KCNE3 mutation and its role in the development of Brugada syndrome. Circ Arrhythm Electrophysiol. 2008; 1:209-218. [PubMed: 19122847]

40. Hu D, Barajas-Martinez H, Burashnikov E, Springer M, Wu Y, Varro A, Pfeiffer R, Koopmann TT, Cordeiro JM, Guerchicoff A, Pollevick GD, Antzelevitch C. Use \{13757\}. Circ Cardiovasc Genet. 2009; 2:270-278. [PubMed: 20031595]

41. Medeiros-Domingo A, Tan BH, Crotti L, Tester DJ, Eckhardt L, Cuoretti A, Kroboth SL, Song C, Zhou Q, Kopp D, Schwartz PJ, Makielski JC, Ackerman MJ. Gain-of-function mutation S422L in the KCNJ8-encoded cardiac K(ATP) channel Kir6.1 as a pathogenic substrate for J-wave syndromes. Heart Rhythm. 2010; 7:1466-1471. [PubMed: 20558321]

42. Giudicessi JR, Ye D, Tester DJ, Crotti L, Mugione A, Nesterenko VV, Albertson RM, Antzelevitch C, Schwartz PJ, Ackerman MJ. Transient outward current (Ito) gain-of-function mutations in the KCND3-encoded Kv4.3 potassium channel and Brugada syndrome. Heart Rhythm. 2011 In press.

43. Haissaguerre M, Chatel S, Sacher F, Weerasooriya R, Probst V, Loussouarn G, Horlitz M, Liersch R, Schulze-Bahr E, Wilde A, Kaab S, Koster J, Rudy Y, Le MH, Schott JJ. Ventricular fibrillation with prominent early repolarization associated with a rare variant of $\mathrm{KCNJ} 8 / \mathrm{K}_{\mathrm{ATP}}$ channel. J Cardiovasc Electrophysiol. 2009; 20:93-98. [PubMed: 19120683]

44. Qi X, Sun F, An X, Yang J. A case of Brugada syndrome with ST segment elevation through entire precordial leads. Chin J Cardiol. 2004; 32:272-273.

45. Watanabe H, Makiyama T, Koyama T, Kannankeril PJ, Seto S, Okamura K, Oda H, Itoh H, Okada M, Tanabe N, Yagihara N, Kamakura S, Horie M, Aizawa Y, Shimizu W. High prevalence of early repolarization in short QT syndrome. Heart Rhythm. 2010; 7:647-652. [PubMed: 20206319]

46. Merchant FM, Noseworthy PA, Weiner RB, Singh SM, Ruskin JN, Reddy VY. Ability of terminal QRS notching to distinguish benign from malignant electrocardiographic forms of early repolarization. Am J Cardiol. 2009; 104:1402-1406. [PubMed: 19892058]

47. Tikkanen JT, Junttila MJ, Anttonen O, Aro AL, Luttinen S, Kerola T, Sager SJ, Rissanen HA, Myerburg RJ, Reunanen A, Huikuri HV. Early Repolarization: Electrocardiographic Phenotypes Associated With Favorable Long-Term Outcome. Circulation. 2011

48. Fish JM, Antzelevitch C. Role of sodium and calcium channel block in unmasking the Brugada syndrome. Heart Rhythm. 2004; 1:210-217. [PubMed: 15851155]

49. Di Diego JM, Cordeiro JM, Goodrow RJ, Fish JM, Zygmunt AC, Peréz GJ, Scornik FS, Antzelevitch C. Ionic and cellular basis for the predominance of the Brugada syndrome phenotype in males. Circulation. 2002; 106:2004-2011. [PubMed: 12370227] 


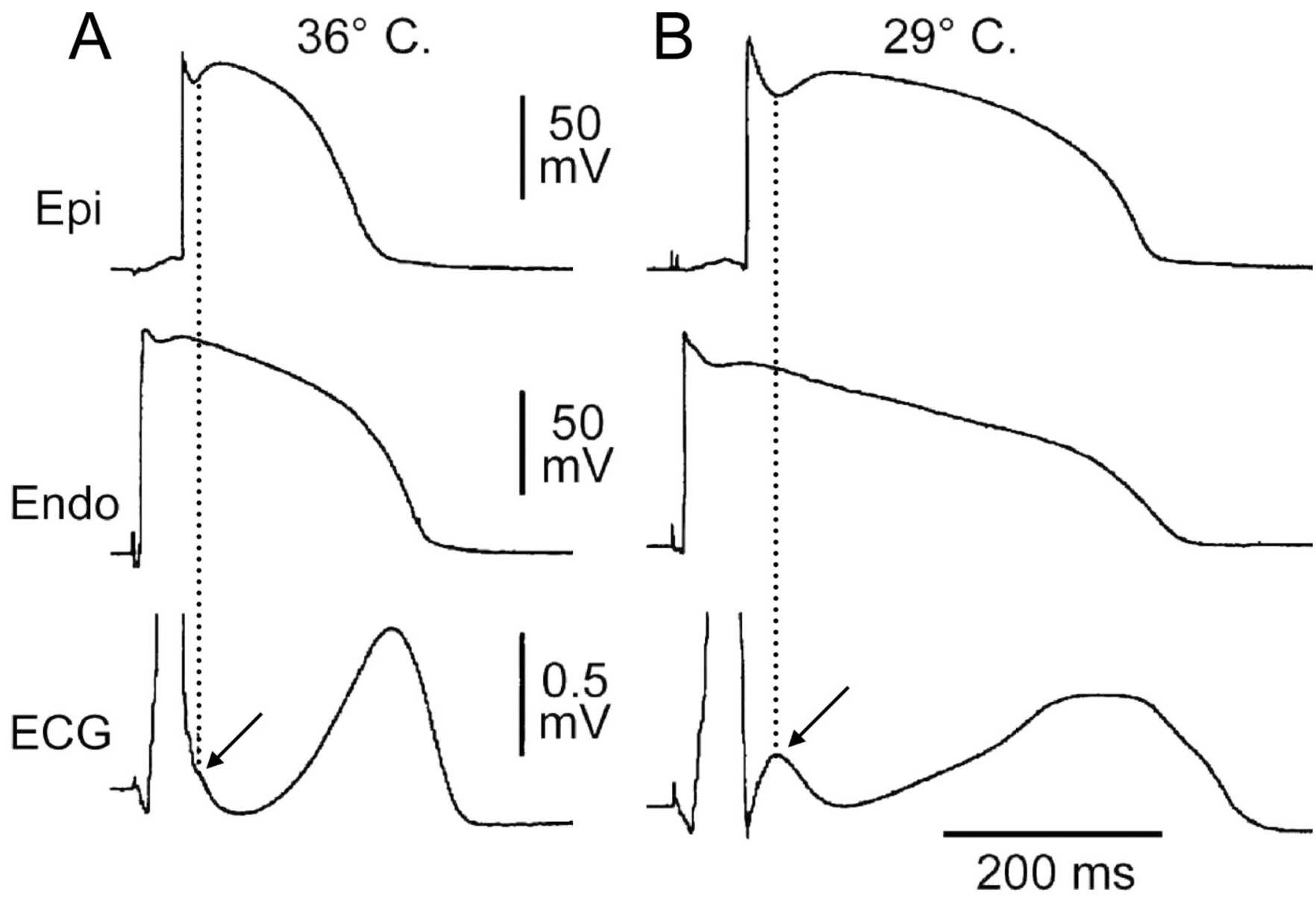

Figure 1.

Hypothermia-induced $\mathbf{J}$ wave. Each panel shows transmembrane action potentials from the epicardial and endocardial regions of an arterially perfused canine left ventricular wedge and a transmural ECG simultaneously recorded. A: The relatively small action potential notch in epicardium but not in endocardium is associated with an elevated J-point at the R-ST junction (arrow) at $36^{\circ} \mathrm{C}$. D: A decrease in the temperature of the perfusate to $29^{\circ} \mathrm{C}$ results in an increase in the amplitude and width of the action potential notch in epicardium but not endocardium, leading to the development of a transmural voltage gradient that manifests as a prominent $\mathbf{J}$ wave on the ECG (arrow). (Modified from ${ }^{7}$, with permission) 


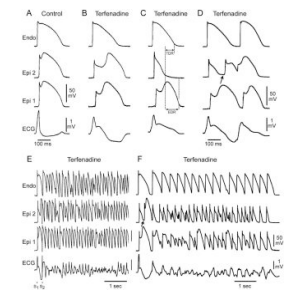

\section{Figure 2.}

Cellular basis for electrocardiographic and arrhythmic manifestation of BrS. Each panel shows transmembrane action potentials from one endocardial (top) and two epicardial sites together with a transmural ECG recorded from a canine coronary-perfused right ventricular wedge preparation. A: Control (Basic cycle length (BCL) $400 \mathrm{msec}$ ). B: Combined sodium and calcium channel block with terfenadine $(5 \mu \mathrm{M})$ accentuates the epicardial action potential notch creating a transmural voltage gradient that manifests as a ST segment elevation or exaggerated $\mathrm{J}$ wave in the ECG. C: Continued exposure to terfenadine results in all-or-none repolarization at the end of phase 1 at some epicardial sites but not others, creating a local epicardial dispersion of repolarization (EDR) as well as a transmural dispersion of repolarization (TDR). D: Phase 2 reentry occurs when the epicardial action potential dome propagates from a site where it is maintained to regions where it has been lost giving rise to a closely coupled extrasystole. E: Extrastimulus ( $1-\mathrm{S} 2=250 \mathrm{msec})$ applied to epicardium triggers a polymorphic VT. F: Phase 2 reentrant extrasystole triggers a brief episode of polymorphic VT. (Modified from reference ${ }^{48}$, with permission) 


\section{A Early Repolarization Syndrome in a Healthy Young Male}

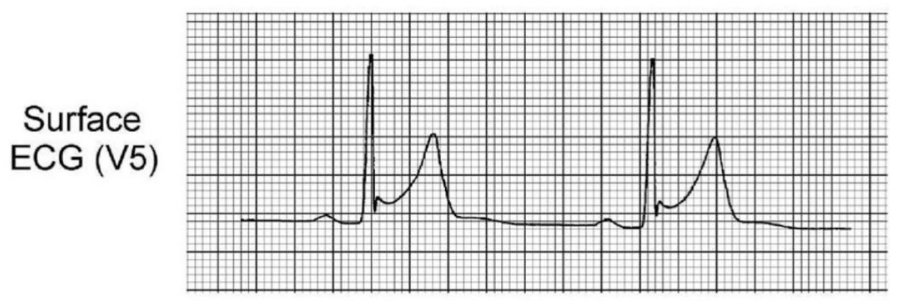

B Canine Ventricular Action Potentials and ECG

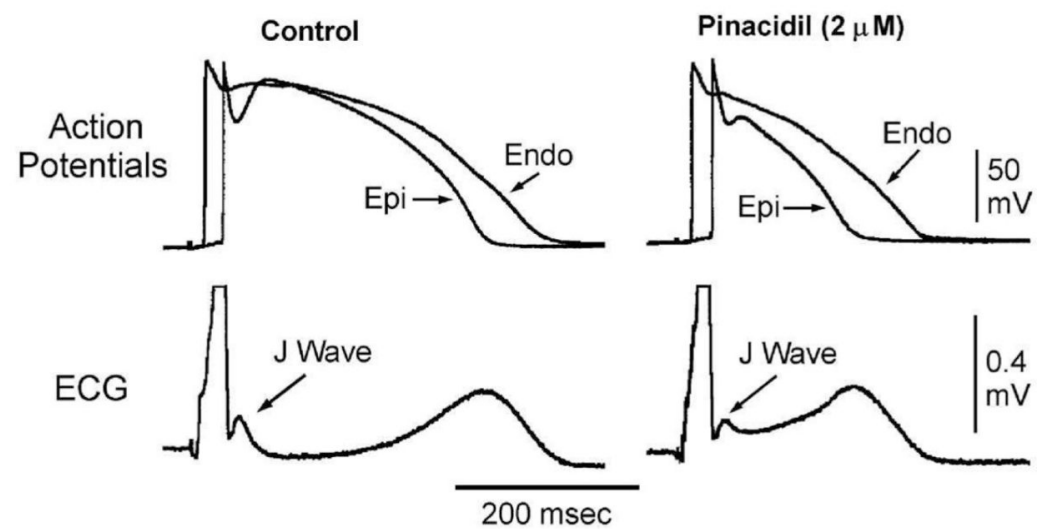

C
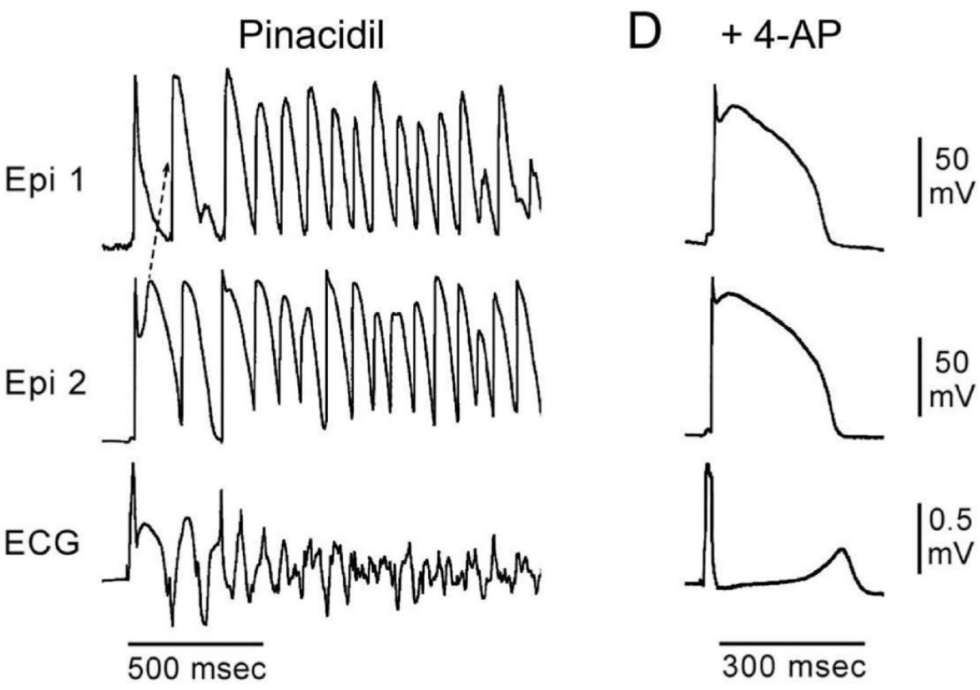

Figure 3.

Cellular basis for the early repolarization syndrome. $\boldsymbol{A}$ : Surface ECG (lead V5) recorded from a 17-year-old healthy African American male. Note the presence of a small $\mathrm{J}$ wave and marked ST segment elevation. B: Simultaneous recording of transmembrane action potentials from epicardial (Epi) and endocardial (Endo) regions and a transmural ECG in an isolated arterially perfused canine left ventricular wedge. A J wave in the transmural ECG is manifest due to the presence of an action potential notch in epicardium but not endocardium. Pinacidil $(2 \mu \mathrm{M})$, an ATP-sensitive potassium channel opener, causes depression of the action potential dome in epicardium, resulting in ST segment elevation in the ECG resembling the early repolarization syndrome. Reprinted from Yan et al. ${ }^{23}$ with permission. 
C: $\mathrm{I}_{\mathrm{K}-\mathrm{ATP}}$ activation in the canine right ventricular wedge preparation using $2.5 \mathrm{uM}$ pinacidil produces heterogeneous loss of the AP dome in epicardium, resulting in ST segment elevation, phase 2 reentry and VT/VF (BrS phenotype). D: The I $\mathrm{t}_{\text {to }}$ blocker, 4aminopyridine (4-AP), restored the epicardial action potential (AP) dome, reduced both transmural and epicardial dispersion of repolarization, normalized the ST segment and prevented phase 2 reentry and VT/VF in the continued presence of pinacidil. (Modified from ${ }^{49}$, with permission). 


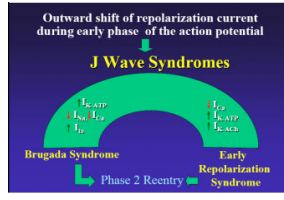

Figure 4.

J wave Syndromes. Schematic depicting our working hypothesis that an outward shift in repolarizing current due to a decrease in sodium or calcium channel currents or an increase in $\mathrm{I}_{\text {to }}, \mathrm{I}_{\mathrm{K}-\mathrm{ATP}}$ or $\mathrm{I}_{\mathrm{K}-\mathrm{ACh}}$, or other outward currents can give rise to accentuated $\mathrm{J}$ waves associated with the BrS, Early Repolarization Syndrome and some forms of IVF. (Modified from ${ }^{1}$, with permission) 